\title{
A perspective on perovskite oxide semiconductor catalysts for gas phase photoreduction of carbon dioxide
}

\author{
Chunxiang Huang, Zhaosheng Li, and Zhigang Zou, National Laboratory of Solid State Microstructures, College of Engineering and Applied \\ Sciences, Ecomaterials and Renewable Energy Research Center (ERERC), Nanjing University, No. 22 Hankou Road, Nanjing 210093, People's Republic of \\ China \\ Address all correspondence to Zhaosheng Li or Zhigang Zou at zsli@nju.edu.cn or zgzou@nju.edu.cn
}

(Received 15 June 2016; accepted 8 August 2016)

\begin{abstract}
Photocatalytic reduction of carbon dioxide $\left(\mathrm{CO}_{2}\right)$ into renewable hydrocarbon fuels using solar energy has gained much attention in the effort to conserve energy and enhance carbon cycling. This paper begins with a brief description of the basic concepts of the photocatalytic reduction of $\mathrm{CO}_{2}$, introduces some experimental challenges in the gas photoreaction system and provides a review of perovskite oxide semiconductor catalysts, including tantalates, niobates, titanates, zirconates and cerates, for use in the gas phase photoreduction of $\mathrm{CO}_{2}$. The prospects for the future research of $\mathrm{CO}_{2}$ photoreduction are also presented.
\end{abstract}

\section{Introduction}

Recently, there are increasing concerns of energy and environmentalism due, in part, to the growing consumption of nonrenewable fossil fuels and the rising atmospheric levels of carbon dioxide $\left(\mathrm{CO}_{2}\right)$, a major greenhouse gas that is considered to be a major contributor to global warming and other unforeseen severe consequences. The photocatalytic reduction of $\mathrm{CO}_{2}$ into hydrocarbons using solar energy, often referred to as artificial photosynthesis, is believed to be a potential and promising approach to solve both issues. ${ }^{[1-5]}$ Since the reduction of $\mathrm{CO}_{2}$ by a $\mathrm{TiO}_{2}$ photocatalyst was reported by Inoue and Fujishima's group, ${ }^{[6]}$ the photocatalytic reduction of $\mathrm{CO}_{2}$ has attracted the attention of many researchers. The key to this process is to develop an efficient photocatalyst that can properly position the valence and conduction bands for the oxidation and reduction half-reactions of water and $\mathrm{CO}_{2}$, respectively. ${ }^{[5,7]}$ To date, various photocatalysts (such as $\mathrm{TiO}_{2},{ }^{[8]} \mathrm{CdS},{ }^{[9]}$ $\mathrm{GaP},{ }^{[10]} \mathrm{Zn}_{2} \mathrm{GeO}_{4},{ }^{[11]}$ etc.) have been used for photocatalytic $\mathrm{CO}_{2}$ reduction. Usually, the photocatalysts with an ideal perovskite structure are expected to exhibit good photocatalytic activity, which has been demonstrated in many studies. ${ }^{[12,13]}$ Recently, a series of perovskite type materials of the form $\mathrm{ABO}_{3}$ (such as $\mathrm{BaZrO}_{3},{ }^{[14]} \mathrm{BaCeO}_{3},{ }^{[15]} \mathrm{SrTiO}_{3},{ }^{[16]}$ etc.) have been studied in the photocatalytic reduction of $\mathrm{CO}_{2}$.

Although the photocatalytic reduction of $\mathrm{CO}_{2}$ has been well studied, the conversion efficiency of $\mathrm{CO}_{2}$ is still very low compared with that of water splitting. ${ }^{[3,4]}$ Two major photocatalytic systems are being studied: a solid-liquid interface prepared by an aqueous dispersion of photocatalysts and a solid-gas interface. ${ }^{[5]}$ Usually, both the liquid-phase $\left(\mathrm{CH}_{3} \mathrm{OH}, \mathrm{HCHO}\right.$, $\mathrm{HCOOH})$ and gas-phase $\left(\mathrm{CH}_{4}\right)$ products can be detected in a liquid photoreaction system, whereas only gas-phase $\left(\mathrm{CH}_{4}\right.$, $\mathrm{CO})$ products could be detected in a gas photoreaction system. ${ }^{[7]}$ Although the solid-liquid reaction interface increases the accessible area for carriers and reactants, this approach has two drawbacks: the rather low solubility of $\mathrm{CO}_{2}$ and the reduction of water competing with $\mathrm{CO}_{2}$ reduction in the aqueous suspensions. Although the solid-gas reaction interface promotes the separation of products and reactants, the ratio of gaseous $\mathrm{CO}_{2}$ and $\mathrm{H}_{2} \mathrm{O}$ is easily tunable, which thus inhibits competitive water reduction. ${ }^{[17,18]}$ Because the products of the photocatalytic reduction of $\mathrm{CO}_{2}$ are mostly $\mathrm{C} 1$ compounds, it is necessary to eliminate the effects of any organic or carbon residues on the whole photocatalytic reaction process because organic molecules (e.g., acetic acid) or carbon residues may undergo the photo-Kolbe reaction, photodegradation, photolysis reactions or reverse disproportionation reactions on the photocatalyst. ${ }^{[19,20]}$

This paper begins with a brief description of the basic concepts of the photocatalytic reduction of $\mathrm{CO}_{2}$ and introduces some experimental problems encountered in the gas photoreaction system. In addition, this paper reviews perovskite oxide semiconductor catalysts used in the photocatalytic reduction of $\mathrm{CO}_{2}$. The prospects for future developments of $\mathrm{CO}_{2}$ photoreduction are also presented.

\section{Basic concepts of the photocatalytic reduction of $\mathrm{CO}_{2}$}

$\mathrm{CO}_{2}$ photoreduction is the conversion of $\mathrm{CO}_{2}$ into hydrocarbon fuels using sunlight, which is also known as artificial photosynthesis. Because $\mathrm{CO}_{2}$ is one of the most thermodynamically stable carbon compounds and because it cannot absorb light in the 


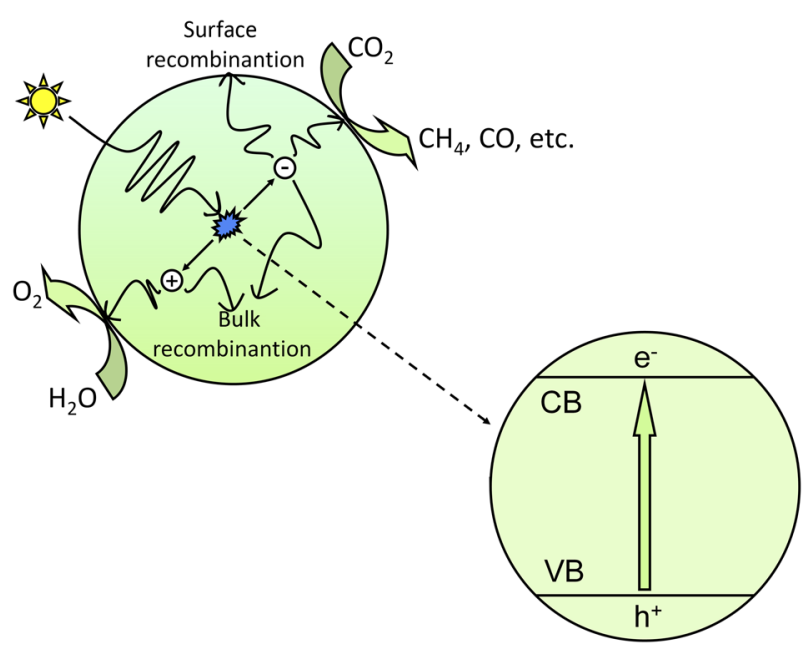

Figure 1. Schematic illustration of the photoexcitation and electron transfer process for the photocatalytic reduction of $\mathrm{CO}_{2}$ with $\mathrm{H}_{2} \mathrm{O}$ as a reductant.

wavelengths of $200-900 \mathrm{~nm}$, the $\mathrm{CO}_{2}$ photoreduction process requires a suitable photosensitizer, which is generally a semiconductor catalyst. ${ }^{[21,22]}$ Figure 1 shows the basic mechanism for the photocatalytic process of $\mathrm{CO}_{2}$ reduction. In the photocatalytic process, photons having energy greater than or equal to the band gap energy are absorbed by the semiconductor, and the electrons in the valence band (VB) are excited to the conduction band (CB). Consequently, equal numbers of electrons and holes are generated in the $\mathrm{CB}$ and $\mathrm{VB}$, respectively. The photogenerated electron-hole pairs separate from each other and transfer to the active sites on the surface of semiconductors; then, the photogenerated electrons with strong reduction potential reduce $\mathrm{CO}_{2}$ into hydrocarbons such as $\mathrm{CH}_{4}$ and $\mathrm{CO}$, etc., and the photogenerated holes with strong oxidation potential oxidize $\mathrm{H}_{2} \mathrm{O}$ into $\mathrm{O}_{2}$.

However, not all photogenerated electron-hole pairs reaching the surface of semiconductor catalysts can participate in the redox reaction, as the energy of the photogenerated electronhole pairs must meet a certain thermodynamic conditions. ${ }^{[5,21]}$ That is, the bottom of the CB of the semiconductor photocatalysts should have a more negative potential than the reduction potential of $\mathrm{CO}_{2}$ forming $\mathrm{HCOOH}, \mathrm{CO}, \mathrm{HCHO}, \mathrm{CH}_{3} \mathrm{OH}$ and $\mathrm{CH}_{4}$; likewise, the top of the VB should have a more positive potential than the oxidation potential of $\mathrm{H}_{2} \mathrm{O}$. Equations (1)(8) show the possible reactions involved in $\mathrm{CO}_{2}$ photoreduction and their corresponding theoretical potentials (vs. the normal hydrogen electrode in an aqueous solution at $\mathrm{pH} 7$ and $25^{\circ} \mathrm{C}$, assuming unit activity). ${ }^{[4,5,21]}$

$$
\begin{gathered}
\mathrm{CO}_{2}+\mathrm{e}^{-} \rightarrow \mathrm{CO}_{2}^{\bullet-} ; \quad E^{0}=-1.90 \mathrm{~V} \\
\mathrm{CO}_{2}+2 \mathrm{H}^{+}+2 \mathrm{e}^{-} \rightarrow \mathrm{HCOOH} ; \quad E^{0}=-0.61 \mathrm{~V} \\
\mathrm{CO}_{2}+2 \mathrm{H}^{+}+2 \mathrm{e}^{-} \rightarrow \mathrm{CO}+\mathrm{H}_{2} \mathrm{O} ; \quad E^{0}=-0.53 \mathrm{~V}
\end{gathered}
$$

$$
\begin{gathered}
\mathrm{CO}_{2}+4 \mathrm{H}^{+}+4 \mathrm{e}^{-} \rightarrow \mathrm{HCHO}+\mathrm{H}_{2} \mathrm{O} ; \quad E^{0}=-0.48 \mathrm{~V} \\
\mathrm{CO}_{2}+6 \mathrm{H}^{+}+6 \mathrm{e}^{-} \rightarrow \mathrm{CH}_{3} \mathrm{OH}+\mathrm{H}_{2} \mathrm{O} ; \quad E^{0}=0.38 \mathrm{~V} \\
\mathrm{CO}_{2}+8 \mathrm{H}^{+}+8 \mathrm{e}^{-} \rightarrow \mathrm{CH}_{4}+2 \mathrm{H}_{2} \mathrm{O} ; \quad E^{0}=-0.24 \mathrm{~V} \\
2 \mathrm{H}^{+}+2 \mathrm{e}^{-} \rightarrow \mathrm{H}_{2} ; \quad E^{0}=-0.41 \mathrm{~V} \\
2 \mathrm{H}_{2} \mathrm{O}+4 \mathrm{~h}^{+} \rightarrow \mathrm{O}_{2}+4 \mathrm{H}^{+} ; \quad E^{0}=0.82 \mathrm{~V}
\end{gathered}
$$

From a thermodynamic point of view, ${ }^{[21,23]}$ the reaction of one electron to form $\mathrm{CO}_{2}{ }^{--}$is highly unfavorable due to the very negative reduction potential of $-1.9 \mathrm{~V}$ (vs. NHE) for this process [Eq. (1)]. Thus, many researchers believe that the photocatalytic reduction of $\mathrm{CO}_{2}$ is a multi-electronic process, which requires less energy for electron transfer compared with a mono-electronic process [Eqs. (2)-(6)]. In the multi-electron $\mathrm{CO}_{2}$ reduction pathway, the reaction requires the assistance of a corresponding number of protons [Eq. (8)]. The formation of products could be different, which is determined by the number of photogenerated electron-hole pairs participating in the redox reaction.

Although photocatalytic reduction of $\mathrm{CO}_{2}$ has been well studied, the $\mathrm{CO}_{2}$ conversion efficiency of this process is still very low. In addition to a suitable $E_{\mathrm{g}}$ and CB potential, many factors influence the conversion efficiency of the multi-electron $\mathrm{CO}_{2}$ photocatalytic reduction process. These factors include excitation, transport, separation (recombination) of the photogenerated electron-hole pairs, the adsorption capacity of the gas molecules, the reduction of $\mathrm{CO}_{2}$, the oxidation of $\mathrm{H}_{2} \mathrm{O}$, and so on. Furthermore, the selective formation of specific products is also a considerable problem in the photocatalytic reduction of $\mathrm{CO}_{2} \cdot{ }^{[3,4]}$ So far, many strategies, including increased visiblelight excitation (e.g., impurity doping, sensitization, ${ }^{[24]}$ and solid solution construction $\left.{ }^{[25]}\right)$, improved transport and separation of the photogenerated electron-hole pairs (e.g., loading with cocatalysts, ${ }^{[26]}$ synthesis of nanostructured photocatalysts, ${ }^{[27]}$ and construction of semiconductor heterojunctions ${ }^{[28]}$ ), enhanced adsorption of $\mathrm{CO}_{2}$ (e.g., increasing the surface $\operatorname{area}^{[29]}$, and suppression off-target side reactions (e.g., the competitive reaction of $\mathrm{H}_{2} \mathrm{O}$ reduction in Eq. $\left.(7)^{[30]}\right)$, etc., have been designed to achieve a high efficiency and selectivity.

\section{Key points of the experimental details}

The efficiency of the photocatalytic reduction of $\mathrm{CO}_{2}$ depends not only on the factors mentioned above, a suitable semiconductor photocatalyst (with proper $E_{\mathrm{g}}, \mathrm{CB}$ and $\mathrm{VB}$ ), the excitation, transport and separation (recombination) of the photogenerated electron-hole pairs, etc., but also on the experimental conditions, ${ }^{[20,31-33]}$ such as the light source, response time, reaction temperature, the ratio of $\mathrm{H}_{2} \mathrm{O}$ and $\mathrm{CO}_{2}$, etc.

Photocatalytic reduction of $\mathrm{CO}_{2}$ is mainly carried out at room pressure and temperature and is controlled by a cooling water recirculation system. A high pressure mercury lamp 
and/or a $300 \mathrm{~W}$ xenon lamp, usually with a cutoff filter, are the most common light sources in $\mathrm{CO}_{2}$ photoreduction. Yahaya et al. found that the traditional UV lamp had a drawback in that the light intensity would decrease with rising temperature due to the lengthy illumination time, and this decrease affects the efficiency of $\mathrm{CO}_{2}$ photocatalytic reduction. ${ }^{[31]}$ The selection of response time for the studies of $\mathrm{CO}_{2}$ photoreduction is different, ranging from tens of minutes to hours. Zhao et al. studied nano-sized $\mathrm{CoPc} / \mathrm{TiO}_{2}$ particles as a catalyst for photoconversion of $\mathrm{CO}_{2}$ and discussed the effect of irradiation time on the formation of photo-reduced products over a period of 650 h. ${ }^{[32]}$ At short reaction times, the product yields increased rapidly because more photoelectrons were generated with increasing time of light exposure; however, the product yields flattened out after $20 \mathrm{~h}$ of irradiation. This result can be attributed to saturation of the reactive surface active sites absorbed with intermediate products. In addition, the molar ratio of $\mathrm{H}_{2} \mathrm{O}$ and $\mathrm{CO}_{2}$ is also found to play an important role in determining the reaction rate and product selectivity for $\mathrm{CO}_{2}$ photocatalytic reduction. Zhang et al. investigated the photocatalytic reduction of $\mathrm{CO}_{2}$ with $\mathrm{H}_{2} \mathrm{O}$ on a Pt-loaded $\mathrm{TiO}_{2}$ catalyst and studied the effect of the $\mathrm{H}_{2} \mathrm{O} / \mathrm{CO}_{2}$ molar ratio on $\mathrm{CH}_{4}$ yield. They found that the $\mathrm{CH}_{4}$ yield of 0.15 wt.\% Pt-loaded $\mathrm{TiO}_{2}$ nanotube increased as the mole ratio of $\mathrm{H}_{2} \mathrm{O}$ and $\mathrm{CO}_{2}$ increased, while the different $\mathrm{H}_{2} \mathrm{O}: \mathrm{CO}_{2}$ molar ratios had little effect on the $\mathrm{CH}_{4}$ yield of $0.12 \mathrm{wt} . \%$ Pt-loaded $\mathrm{TiO}_{2}$ nanoparticles. ${ }^{[33]}$ The formation of $\mathrm{CH}_{4}$ occurred mainly due to the high concentration of the surface $\mathrm{OH}$ group, which had been shown previously by Ikeue et al. ${ }^{[34]}$

The main products in a gas phase reaction system for photocatalytic reduction of $\mathrm{CO}_{2}$ are generally $\mathrm{CH}_{4}$, which is usually on the $\mu \mathrm{mol}$ scale, as well as a small amount of $\mathrm{CO} \cdot{ }^{[8,14-16]} \mathrm{As}$ we mentioned above, the photocatalytic reduction of $\mathrm{CO}_{2}$ is a complex multi-electronic reaction process. There are two plausible pathways for $\mathrm{CH}_{4}$ formation ${ }^{[4,20]}$ :

$$
\begin{gathered}
\mathrm{CO}_{2} \rightarrow \mathrm{HCOOH} \rightarrow \mathrm{HCHO} \rightarrow \mathrm{CH}_{3} \mathrm{OH} \rightarrow \mathrm{CH}_{4} \\
\mathrm{CO}_{2} \rightarrow \mathrm{CO} \rightarrow \mathrm{CO}_{2}^{\cdot-} \rightarrow \mathrm{CH}_{2} \rightarrow \mathrm{CH}_{4}
\end{gathered}
$$

It is necessary to verify whether the carbon source for $\mathrm{CH}_{4}$ production is actually the $\mathrm{CO}_{2}$ for the gaseous $\mathrm{CO}_{2}$ reduction because any organic adsorbates or carbon residues may take part in side reactions, such as the photo-Kolbe reaction, mineralization reaction, photolysis reaction or reverse disproportionation reaction. ${ }^{[19,20]}$ These reactions could create a false impression of the formation of hydrocarbon products.

If there are any carbon residues deposited or buried on the surface of catalyst during the preparation of the catalyst for the photocatalytic reduction of $\mathrm{CO}_{2}$, a reverse disproportionation reaction of the impurity might occur in the presence of $\mathrm{CO}_{2}$ in the reaction system. In this case, the generated $\mathrm{CO}$ would react with the water adsorbed on the surface active sites of the catalyst; then, the generated $\mathrm{CH}_{3} \mathrm{OH}$ would ultimately generate $\mathrm{CH}_{4}$. This pathway has been shown by Yang et al. through the combined use of in situ diffuse reflectance infrared Fourier transform spectroscopy (DRIFTS) and ${ }^{13} \mathrm{C}$ labeled $\mathrm{CO}_{2}$ during $\mathrm{CO}_{2}$ photoreduction over $\mathrm{Cu}$-promoted crystalline $\mathrm{TiO}_{2}$ catalysts. The reaction process could be described as follows ${ }^{[19,35]}$ :

$$
\begin{gathered}
\mathrm{C} \text { (impurity in or on catalyst) }+\mathrm{CO}_{2} \rightarrow \mathrm{CO}+\mathrm{CO} \\
\mathrm{CO}+2 \mathrm{H}_{2} \mathrm{O} \rightarrow \mathrm{CH}_{3} \mathrm{OH}+\mathrm{O}_{2}
\end{gathered}
$$

Yui et al. demonstrated that organic adsorbates, especially $\mathrm{CH}_{3} \mathrm{COOH}$, had a significant effect on the formation of $\mathrm{CH}_{4}$ in $\mathrm{CO}_{2}$ photoreduction over $\mathrm{TiO}_{2}$. The organic adsorbed on the surface of $\mathrm{TiO}_{2}$ could participate in a so-called photo-Kolbe reaction $\left(\mathrm{CH}_{3} \mathrm{COOH} \text {, for example }\right)^{[36]}$ :

$$
\begin{gathered}
\mathrm{CH}_{3} \mathrm{COOH}+\mathrm{h}^{+} \rightarrow{ }^{\bullet} \mathrm{CH}_{3}+\mathrm{CO}_{2}+\mathrm{H}^{+} \\
\cdot \mathrm{CH}_{3}+\mathrm{CH}_{3} \mathrm{COOH} \rightarrow{ }^{\bullet} \mathrm{CH}_{2} \mathrm{COOH}+\mathrm{CH}_{4}
\end{gathered}
$$

In addition, if there are any alcohols and $\mathrm{O}_{2}$ in the $\mathrm{CO}_{2}$ photoreduction reaction system producing $\mathrm{CH}_{4}, \mathrm{CO}_{2}$ would be generated in-situ due to the mineralization of alcohols on the surface of the semiconductor photocatalyst, which could be explained through the following mechanism ${ }^{[20]}$ :

$$
\text { Organic radical }(\mathrm{OR})+\mathrm{O}_{2} \rightarrow \mathrm{CO}_{2}
$$

In conclusion, evaluations of the products for $\mathrm{CO}_{2}$ photocatalytic reduction should be interpreted with caution. In other words, the $\mathrm{C}$ source should be carefully investigated with respect to the production of $\mathrm{CH}_{4}$ and $\mathrm{CO}$ from $\mathrm{CO}_{2}$ in a gaseous $\mathrm{CO}_{2}$ photoreduction system. Most researchers carry out a series of contrast experiments with different conditions including $\mathrm{H}_{2} \mathrm{O}, \mathrm{CO}_{2}$, irradiation and catalyst to exclude the effects of carbon residues and organic adsorbates on the formation of hydrocarbon products $^{[14-16]}$; some other studies, however, reported a more precise and intuitive method: isotopic labeling $\left({ }^{13} \mathrm{C}\right.$ and $\left.{ }^{18} \mathrm{O}\right) .{ }^{[35-37]}$ This approach can simultaneously evaluate the $\mathrm{C}$ source and the $\mathrm{O}$ source. To guarantee the reliability of the results of $\mathrm{CO}_{2}$ photocatalytic reduction, carbon residues or organic adsorbates must be avoided throughout the entire reaction system. These residues and adsorbates may form during the synthesis of the catalyst if it involves the use of alkoxides and organic solvents (e.g., polyethylene glycol, PEG) as precursors or in washing steps if organic cleaning solvents are used. $^{[35,38,39]}$ These residues could be removed using particular methods, such as thermal treatment in a continuous flow of $\mathrm{N}_{2}$ or Ar inert gas or at high temperature in air, as well as prolonged washing in a water environment. ${ }^{[19,35,36]}$

\section{Perovskite oxide semiconductor photocatalysts for gaseous $\mathrm{CO}_{2}$ reduction}

An ideal semiconductor photocatalyst for $\mathrm{CO}_{2}$ photoreduction should benefit from: (1) a suitable $E_{\mathrm{g}}$ such that the 
semiconductor absorbs incident photons over a range of wavelengths to generate electron-hole pairs; (2) effective separation between the photogenerated electron-hole pairs that then transfer to the surface of semiconductors and subsequently take part in the oxidation-reduction reaction with $\mathrm{CO}_{2}$ and $\mathrm{H}_{2} \mathrm{O}$ absorbed on the surface active sites of the semiconductors; and (3) a welltuned $\mathrm{CB}$ and $\mathrm{VB}$ such that the bottom of the $\mathrm{CB}$ is located at a more negative potential than the reduction potentials of $\mathrm{CO}_{2}$ and such that the top of the VB has a more positive potential than the oxidation potential of $\mathrm{H}_{2} \mathrm{O}$. Based on these principles, various photocatalysts, including metal oxides (e.g., $\mathrm{TiO}_{2},{ }^{[8]}$ $\mathrm{ZnO},{ }^{[40]} \mathrm{BiVO}_{4}{ }^{[41]}$ and $\mathrm{Ga}_{2} \mathrm{O}_{3}^{[42]}$ ), metal sulfides (e.g., $\mathrm{CdS}^{[9]}$ and $\mathrm{ZnS}^{[43]}$ ), metal phosphides (e.g., $\mathrm{GaP}^{[10]}$ ), nitrides (e.g., $\mathrm{C}_{3} \mathrm{~N}_{4}^{[44]}$ ), etc., have been reported for $\mathrm{CO}_{2}$ reduction. Among them, perovskite oxide semiconductor photocatalysts are good candidates for $\mathrm{CO}_{2}$ reduction due to their unique physical and chemical properties, including their stability, their controllable structure and their ability to be doped in two different cation sites. In addition, perovskite structures are expected to exhibit good photocatalytic activity as has been demonstrated in many studies. ${ }^{[12,13]}$ Recently, a series of the perovskite type materials of the form $\mathrm{ABO}_{3}$ (such as $\mathrm{BaZrO}_{3},{ }^{[14]}$ $\mathrm{BaCeO}_{3},{ }^{[15]} \mathrm{SrTiO}_{3},{ }^{[16,45,46]}$ etc.) have been studied for the photocatalytic reduction of $\mathrm{CO}_{2}$. Table I shows the summary of perovskite oxide semiconductors used in the photocatalytic reduction of $\mathrm{CO}_{2}$ in a gas reaction system. These semiconductors were roughly divided into five types: tantalates, niobates, titanates, zirconates and cerates.

\section{Tantalates}

Teramura et al. carried out the photoreduction of $\mathrm{CO}_{2}$ over $\mathrm{ATaO}_{3}(\mathrm{~A}=\mathrm{Li}, \mathrm{Na}$ and $\mathrm{K})$ synthesized by a conventional solidstate reaction in the presence of $\mathrm{H}_{2}$. $\mathrm{CO}$ was the only gaseous product over all of the samples tested under $200 \mathrm{~W} \mathrm{Hg}$-Xe lamp irradiation. ${ }^{[54]} \mathrm{LiTaO}_{3}$ presented the highest activity for $\mathrm{CO}$ yield $(0.42 \mu \mathrm{mol} / \mathrm{g}$ in $24 \mathrm{~h})$, and the trend of the photocatalytic activities were consistent with that of the $E_{\mathrm{g}}\left(\mathrm{LiTaO}_{3}>\right.$ $\mathrm{NaTaO}_{3}>\mathrm{KTaO}_{3}$ ). In addition, they also found that the amount of evolved $\mathrm{CO}$ gas depended on the amount of chemisorbed $\mathrm{CO}_{2}$ (as shown in Fig. 2), ${ }^{[54]}$ which meant that the adsorption of $\mathrm{CO}_{2}$ had an effect on the reduction efficiency of $\mathrm{CO}_{2} . \mathrm{H}_{2}$ was used as reductant in this photocatalytic reduction of $\mathrm{CO}_{2}$ process, whereas other gas reaction systems usually used $\mathrm{H}_{2} \mathrm{O}$ as reductant.

\section{Niobates}

Niobates with a perovskite structure share many characteristics with tantalates and have been used in $\mathrm{CO}_{2}$ photocatalytic reduction systems with water as the reductant. Shi et al. studied the photocatalytic reduction activities of $\mathrm{CO}_{2}$ into $\mathrm{CH}_{4}$ over $\mathrm{NaNbO}_{3}$ samples upon irradiation from a Xe arc lamp. It was discovered that the $\mathrm{CH}_{4}$ evolution rate $(653 \mathrm{ppm} / \mathrm{h} / \mathrm{g})$ of Pt-loaded $\mathrm{NaNbO}_{3}$ nanowires prepared by a hydrothermal method were much higher than that of bulk $\mathrm{NaNbO}_{3}$ particles synthesized by a solid-state reaction. ${ }^{[53]}$ Subsequently, they prepared alkali niobate $\mathrm{ANbO}_{3}(\mathrm{~A}=\mathrm{K}, \mathrm{Na})$ photocatalysts using a conventional solid-state reaction method and compared their photocatalytic performance for $\mathrm{CO}_{2}$ reduction under similar conditions. They found that $\mathrm{KNbO}_{3}(7.0 \mathrm{ppm} / \mathrm{h})$ showed a higher photocatalytic activity than $\mathrm{NaNbO}_{3}(2.3 \mathrm{ppm} / \mathrm{h}){ }^{[52]}$ The perovskite $\mathrm{NaNbO}_{3}$ studied in most research has a typical cubic structure, whereas $\mathrm{NaNbO}_{3}$ also has another crystal structure - an orthorhombic structure. The schematic crystal structures of cubic and orthorhombic $\mathrm{NaNbO}_{3}$ are shown in Fig. 3. ${ }^{[51]} \mathrm{Li}$ et al. discussed the photocatalytic activities of $\mathrm{CO}_{2}$ reduction over the cubic and orthorhombic $\mathrm{NaNbO}_{3}$ in a gas phase system and found that the $\mathrm{CO}_{2}$ reduction activity over the cubic $\mathrm{NaNbO}_{3}$ was nearly twice that of the orthorhombic $\mathrm{NaNbO}_{3}$. These results might be due to the unique electron structure of cubic $\mathrm{NaNbO}_{3}$, which may support electron excitation and transfer. ${ }^{[51]}$ In addition, they studied the influence of the preparation temperature on the activity of $\mathrm{NaNbO}_{3}$ photocatalyst. ${ }^{[50]}$ The cubic $\mathrm{NaNbO}_{3}$ prepared at $500^{\circ} \mathrm{C}$ presented the best photocatalytic performances, and the $\mathrm{CH}_{4}$ evolution for gas phase $\mathrm{CO}_{2}$ photoreduction over $\mathrm{NaNbO}_{3}$ loaded with 0.5 wt.\% Pt under a $300 \mathrm{~W}$ Xe lamp $(\lambda>300 \mathrm{~nm})$ could reach $12.6 \mu \mathrm{mol} / \mathrm{m}^{2} / \mathrm{h}$.

Moreover, differing from the simple $\mathrm{ABO}_{3}$-type perovskite semiconduction photocatalysts, lamellar perovskite niobates, such as $\mathrm{HNb}_{3} \mathrm{O}_{8}$ and $\mathrm{KNb}_{3} \mathrm{O}_{8}$, have also been applied in the gas phase photocatalytic reduction of $\mathrm{CO}_{2} \cdot{ }^{[48,49]}$ Figure 4 shows a schematic drawing of the layered structures of $\mathrm{HNb}_{3} \mathrm{O}_{8}$ composed of $2 \mathrm{D} \mathrm{Nb}_{3} \mathrm{O}_{8}^{-}$anion thin sheets of edgeand corner-shared $\mathrm{NbO}_{6}$ octahedral with $\mathrm{H}^{+}$intercalated between the layers. $\mathrm{Li}$ et al. found that hydrothermally synthesized $\mathrm{HNb}_{3} \mathrm{O}_{8}$ and $\mathrm{KNb}_{3} \mathrm{O}_{8}$ nanobelts exhibited much higher yields of $\mathrm{CH}_{4}$ compared with the $\mathrm{HNb}_{3} \mathrm{O}_{8}$ and $\mathrm{KNb}_{3} \mathrm{O}_{8}$ particles prepared by conventional solid-state reactions as well as commercial $\mathrm{TiO}_{2} \cdot{ }^{[48]}$

\section{Titanates}

Several perovskite titanates, such as $\mathrm{SrTiO}_{3}, \mathrm{PbTiO}_{3}$ and $\mathrm{CaTiO}_{3}$, have also been explored for gas phase $\mathrm{CO}_{2}$ photocatalytic reduction. ${ }^{[16,45-47]}$ Among them, $\mathrm{SrTiO}_{3}$ is the most widely studied photocatalysts. Xie et al. prepared a self-doped $\mathrm{SrTiO}_{3-\delta}$ using a carbon-free one-step combustion, and they demonstrated that the chemical adsorption of $\mathrm{CO}_{2}$ could be improved by increasing the oxygen deficiency of the $\mathrm{SrTiO}_{3}$. This deficiency promoted the photocatalytic activity of $\mathrm{CO}_{2}$ reduction to generate $\mathrm{CH}_{4}$ under visible light irradiation. ${ }^{[16]}$ Zhou et al. discussed a leaf-shaped 3D hierarchical artificial photosynthetic system of $\mathrm{ATiO}_{3}(\mathrm{~A}=\mathrm{Sr}, \mathrm{Ca}$ and $\mathrm{Pb})$ prepared by a modified sol-gel method using fresh green leaves as a structure template. They studied the effects of various cocatalysts $(\mathrm{Au}$, $\mathrm{Ag}, \mathrm{Cu}, \mathrm{Pt}, \mathrm{RuO}_{2}$ and $\mathrm{NiO}_{x}$ ) on the photocatalytic activity of $\mathrm{CO}_{2}$. As shown in Fig. 5, $\mathrm{CH}_{4}$ and $\mathrm{CO}$ were the two main products, and $\mathrm{Au}$ as a suitable cocatalyst exhibited the best performance for the selectivity of both $\mathrm{CH}_{4}$ and $\mathrm{CO}$ (using $\mathrm{SrTiO}_{3}$ as an example) ${ }^{[45]}$ In another study, Kou et al. synthesized a highly active photocatalyst with response to visible light by 
Table I. Summary of perovskite oxide semiconductors for the photocatalytic reduction of $\mathrm{CO}_{2}$ in a gas reaction system.

\begin{tabular}{|c|c|c|c|c|c|c|}
\hline $\begin{array}{l}\text { Catalyst/band gap } \\
\text { energy }\end{array}$ & Co-catalyst & Reaction medium & Light source & $\begin{array}{l}\text { Major } \\
\text { products }\end{array}$ & Yield $^{\mathrm{a}}$ & References \\
\hline $\mathrm{BaZrO}_{3} / 4.8 \mathrm{eV}$ & 0.3 wt. $\% \mathrm{Ag}$ & $\mathrm{CO}_{2}$ and $\mathrm{H}_{2} \mathrm{O}$ vapor & $\begin{array}{r}300 \text { W Xe lamp } \\
\text { (PE 300BUV) }\end{array}$ & $\mathrm{CH}_{4}$ & 0.57 & 14 \\
\hline $\mathrm{BaCeO}_{3} / 3.2 \mathrm{eV}$ & $0.3 w t . \% \mathrm{Ag}$ & $\mathrm{CO}_{2}$ and $\mathrm{H}_{2} \mathrm{O}$ vapor & $\begin{array}{r}300 \text { W Xe lamp } \\
\text { (PE 300BUV) }\end{array}$ & $\mathrm{CH}_{4}$ & 0.55 & 15 \\
\hline $\mathrm{SrTiO}_{3-\delta} / 3.2 \mathrm{eV}$ & $\begin{array}{l}\text { Self-doped } 0.3 \\
\text { wt.\% Pt }\end{array}$ & $\mathrm{CO}_{2}$ and $\mathrm{H}_{2} \mathrm{O}$ vapor & $\begin{array}{c}300 \mathrm{~W} \text { Xe lamp } \\
\lambda>420 \mathrm{~nm}\end{array}$ & $\mathrm{CH}_{4}$ & $0.25^{\mathrm{b}}$ & 16 \\
\hline $\mathrm{SrTiO}_{3} / 3.2 \mathrm{eV}$ & 1 wt. $\% \mathrm{Au}$ & $\mathrm{CO}_{2}$ and $\mathrm{H}_{2} \mathrm{O}$ vapor & $\begin{array}{c}300 \mathrm{~W} \text { Xe lamp } \\
\lambda>420 \mathrm{~nm}\end{array}$ & $\begin{array}{l}\mathrm{CH}_{4} \\
\mathrm{CO}\end{array}$ & $\begin{array}{l}\mathrm{CH}_{4}: 0.231 \\
\mathrm{CO}: 0.349\end{array}$ & 45 \\
\hline $\mathrm{CaTiO}_{3} / 3.5 \mathrm{eV}$ & 1 wt. $\%$ Au & $\mathrm{CO}_{2}$ and $\mathrm{H}_{2} \mathrm{O}$ vapor & $\begin{array}{c}300 \mathrm{~W} \text { Xe lamp } \\
\lambda>420 \mathrm{~nm}\end{array}$ & $\begin{array}{l}\mathrm{CH}_{4} \\
\mathrm{CO}\end{array}$ & $\mathrm{CH}_{4}: 0.029$ & 45 \\
\hline $\mathrm{PbTiO}_{3} / 2.9 \mathrm{eV}$ & 1 wt. $\% \mathrm{Au}$ & $\mathrm{CO}_{2}$ and $\mathrm{H}_{2} \mathrm{O}$ vapor & $\begin{array}{c}300 \mathrm{~W} \text { Xe lamp } \\
\lambda>420 \mathrm{~nm}\end{array}$ & $\begin{array}{l}\mathrm{CH}_{4} \\
\mathrm{CO}\end{array}$ & $\mathrm{CH}_{4}: 0.007$ & 45 \\
\hline $\mathrm{SrTiO}_{3} / 3.2 \mathrm{eV}$ & $\begin{array}{l}\text { 0.02Co doped Pt } \\
\text { loaded }\end{array}$ & $\begin{array}{l}\mathrm{CO}_{2} \text { Gas-closed } \\
\text { system }\end{array}$ & $\begin{array}{c}300 \mathrm{~W} \text { Xe lamp } \\
\lambda>420 \mathrm{~nm}\end{array}$ & $\mathrm{CH}_{4}$ & $63.6^{c}$ & 46 \\
\hline $\begin{array}{c}\mathrm{Ca}_{x} \mathrm{Ti}_{y} \mathrm{O}_{3} / 3.44 \mathrm{eV} \\
(x=y=1)\end{array}$ & - & $\mathrm{CO}_{2}$ and $\mathrm{H}_{2} \mathrm{O}$ vapor & $\begin{array}{c}6 \mathrm{~W} / \mathrm{cm}^{2} \text { UV lamp } \\
\lambda=365 \mathrm{~nm}\end{array}$ & $\mathrm{CH}_{4}$ & $17^{\mathrm{d}}$ & 47 \\
\hline $\begin{array}{l}\mathrm{HNb}_{3} \mathrm{O}_{8} / 3.66 \mathrm{eV} \\
\text { nanobelts }\end{array}$ & - & $\mathrm{CO}_{2}$ and $\mathrm{H}_{2} \mathrm{O}$ vapor & 350 W Xe lamp & $\mathrm{CH}_{4}$ & 3.58 & 48 \\
\hline $\begin{array}{l}\mathrm{HNb}_{3} \mathrm{O}_{8} / 3.5 \mathrm{eV} \\
\quad \mathrm{SiO}_{2}-\mathrm{HNb}_{3} \mathrm{O}_{8} / 3.5 \mathrm{eV}\end{array}$ & 0.4 wt. $\%$ Pt & $\mathrm{CO}_{2}$ and $\mathrm{H}_{2} \mathrm{O}$ vapor & $350 \mathrm{~W}$ Xe lamp & $\mathrm{CH}_{4}$ & $\begin{array}{l}0.47 \\
2.90\end{array}$ & 49 \\
\hline $\begin{array}{c}\mathrm{KNb}_{3} \mathrm{O}_{8} / 3.66 \mathrm{eV} \\
\text { nanobelts }\end{array}$ & - & $\mathrm{CO}_{2}$ and $\mathrm{H}_{2} \mathrm{O}$ vapor & 350 W Xe lamp & $\mathrm{CH}_{4}$ & 1.71 & 48 \\
\hline $\mathrm{NaNbO}_{3} / 3.25 \mathrm{eV}$ & 0.5 wt. $\%$ Pt & $\begin{array}{l}\mathrm{CO}_{2} \text { Gas-closed } \\
\text { system }\end{array}$ & $\begin{array}{c}350 \mathrm{~W} \text { Xe lamp } \\
\lambda>300 \mathrm{~nm}\end{array}$ & $\mathrm{CH}_{4}$ & $12.6^{\mathrm{b}}$ & 50 \\
\hline $\begin{array}{l}\text { c-NaNbO }{ }_{3} / 3.29 \mathrm{eV} \\
0-\mathrm{NaNbO}_{3} / 3.45 \mathrm{eV}\end{array}$ & 0.5 wt. $\%$ Pt & $\mathrm{CO}_{2}$ and $\mathrm{H}_{2} \mathrm{O}$ vapor & 300 W Xe lamp & $\mathrm{CH}_{4}$ & $\begin{array}{l}0.486 \\
0.245\end{array}$ & 51 \\
\hline $\mathrm{NaNbO}_{3} / 3.4 \mathrm{eV}$ & 0.5 wt. $\%$ Pt & $\mathrm{CO}_{2}$ and $\mathrm{H}_{2} \mathrm{O}$ vapor & 300 W Xe lamp & $\mathrm{CH}_{4}$ & $2.3^{\mathrm{c}}$ & 52 \\
\hline $\mathrm{KNbO}_{3} / 3.1 \mathrm{eV}$ & 0.5 wt. $\%$ Pt & $\mathrm{CO}_{2}$ and $\mathrm{H}_{2} \mathrm{O}$ vapor & 300 W Xe lamp & $\mathrm{CH}_{4}$ & $7.0^{\mathrm{C}}$ & 52 \\
\hline $\begin{array}{c}\mathrm{NaNbO}_{3} / 3.4 \mathrm{eV} \\
\text { nanowires }\end{array}$ & 0.5 wt. $\%$ Pt & $\mathrm{CO}_{2}$ and $\mathrm{H}_{2} \mathrm{O}$ vapor & 300 W Xe lamp & $\mathrm{CH}_{4}$ & $653^{e}$ & 53 \\
\hline $\mathrm{LiTaO}_{3} / 4.9 \mathrm{eV}$ & - & $\mathrm{CO}_{2}$ and $\mathrm{H}_{2}$ & 200 W Hg-Xe lamp & $\mathrm{CO}$ & $0.42^{f}$ & 54 \\
\hline $\mathrm{NaTaO}_{3} / 4.1 \mathrm{eV}$ & - & $\mathrm{CO}_{2}$ and $\mathrm{H}_{2}$ & 200 W Hg-Xe lamp & $\mathrm{CO}$ & $0.1^{\dagger}$ & 54 \\
\hline $\mathrm{KTaO}_{3} / 3.7 \mathrm{eV}$ & - & $\mathrm{CO}_{2}$ and $\mathrm{H}_{2}$ & 200 W Hg-Xe lamp & $\mathrm{CO}$ & $0.06^{f}$ & 54 \\
\hline
\end{tabular}

${ }^{a}$ Maximum formation rate reported for the products in $\mu \mathrm{mol} / \mathrm{h} / \mathrm{g}$, unless stated otherwise.

${ }^{\mathrm{b}} \operatorname{In} \mu \mathrm{mol} / \mathrm{m}_{\text {cata }}^{2} / \mathrm{h}$.

In ppm/h.

${ }^{\mathrm{d}}$ The entire yield for the main products in $\mu \mathrm{mol} / \mathrm{g}(7 \mathrm{~h}, x=y=1)$.

${ }^{\mathrm{e}}$ In ppm/h/g.

${ }^{\mathrm{f}}$ The entire yield for the main products in $\mu \mathrm{mol} / \mathrm{g}(24 \mathrm{~h})$.

substituting the $\mathrm{Ti}^{4+}$ in $\mathrm{SrTiO}_{3}$ to transition metal (Co, Fe, Ni) ions for gas phase $\mathrm{CO}_{2}$ reduction, and $\mathrm{Pt}-\mathrm{SrTi}_{0.98} \mathrm{Co}_{0.02} \mathrm{O}_{3}$ had the highest activity (the yield of $\mathrm{CH}_{4}$ was $63.6 \mathrm{ppm} / \mathrm{h}$ ). ${ }^{[4]}$

\section{Zirconates}

Apart from the above-mentioned tantalates, niobates and titanates photocatalysts, Chen et al. first investigated the 

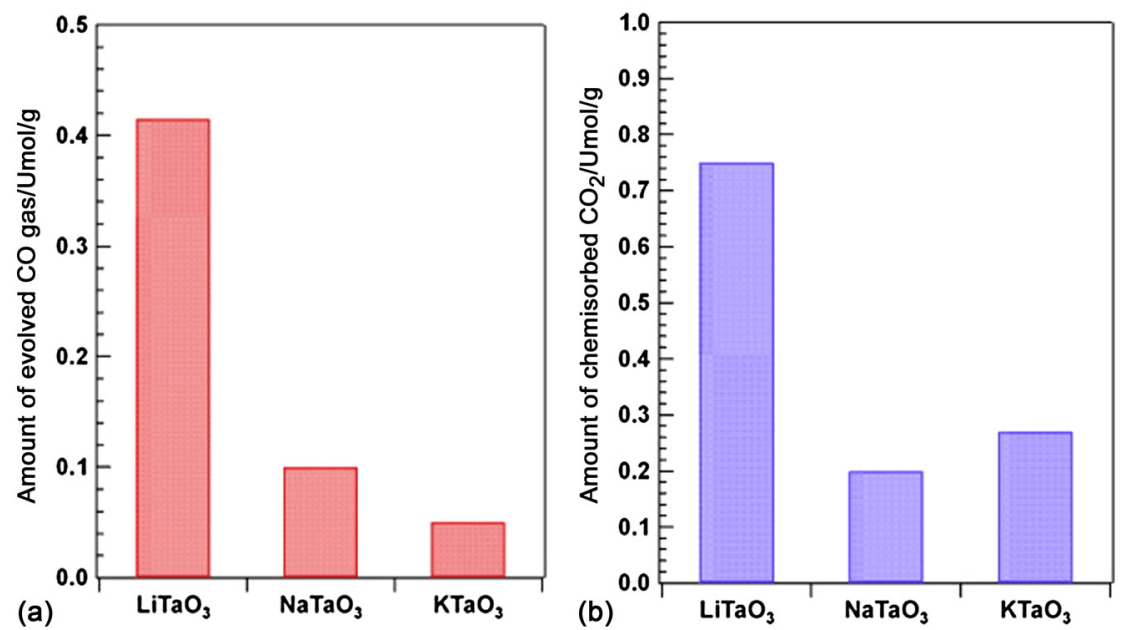

Figure 2. (a) Amount of evolved $\mathrm{CO}$ gas for the photocatalytic reduction of $\mathrm{CO}_{2}$ in the presence of $\mathrm{H}_{2}$ as a reductant over $\mathrm{ATaO}_{3}(\mathrm{~A}=\mathrm{Li}, \mathrm{Na}, \mathrm{K})$ after $24 \mathrm{~h}$ of photoirradiation. (b) Amount of Chemisorbed $\mathrm{CO}_{2}$ on $\mathrm{ATaO}_{3}(\mathrm{~A}=\mathrm{Li}, \mathrm{Na}, \mathrm{K})$. (Copyright 2010, Applied Catalysis B: Environmental. ${ }^{[54]}$ ).

photocatalytic properties of $\mathrm{BaZrO}_{3}$ for $\mathrm{CO}_{2}$ reduction into $\mathrm{CH}_{4}$ in a gas reaction system. ${ }^{[14]}$ Barium zirconate made by the Pechini process has a bandgap of $4.8 \mathrm{eV}$, which means that $\mathrm{BaZrO}_{3}$ only has a UV light response. They also confirmed the effects of different cocatalysts on the photocatalytic activities and optimized the loaded amount of metal nanoparticle cocatalysts. As shown in Fig. 6, Ag was a suitable cocatalyst that
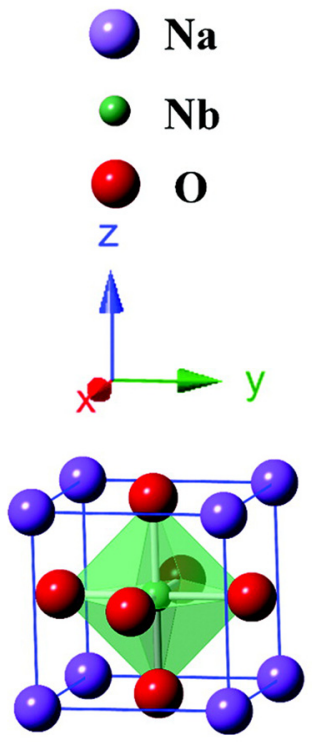

Cubic

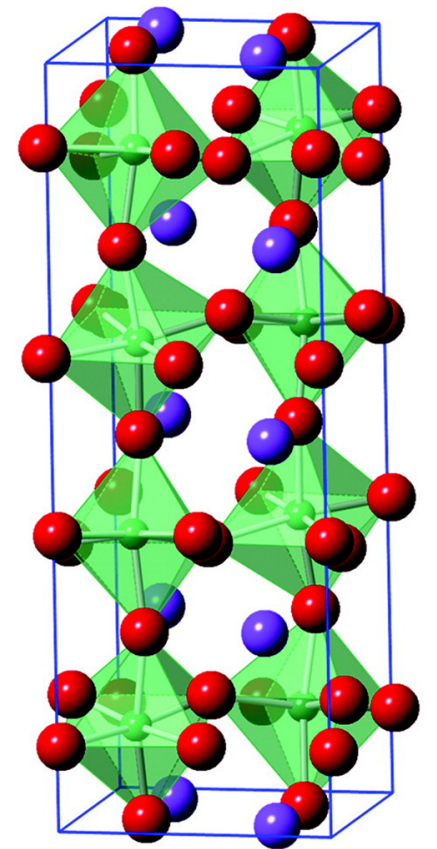

Orthorhombic

Figure 3. Schematic crystal structures of cubic and orthorhombic $\mathrm{NaNbO}_{3}$. (Copyright 2012, The Journal of Physical Chemistry. ${ }^{[51]}$ ).

Figure 4. Schematic drawing of the layered structures of $\mathrm{HNb}_{3} \mathrm{O}_{8}$. 


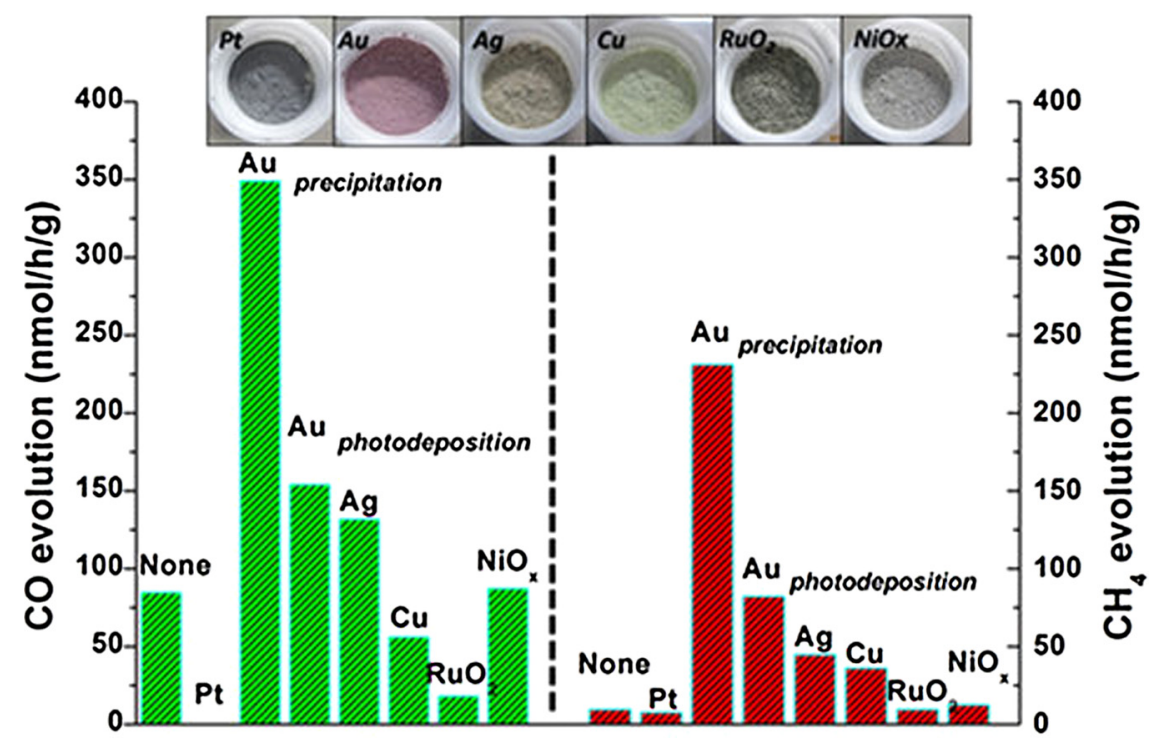

Figure 5. $\mathrm{CO}$ and $\mathrm{CH}_{4}$ evolution on an artificial photosynthetic system of $\mathrm{SrTiO}_{3}$ of $\mathrm{CO}_{2}$ photoreduction loaded with different cocatalysts. (Copyright 2013, Scientific Reports. ${ }^{[45]}$ ).

photocatalytic reduction of $\mathrm{CO}_{2}$ into $\mathrm{CH}_{4}$ over $\mathrm{BaCeO}_{3}$ loaded with $0.3 \mathrm{wt} \% \mathrm{Ag}$ cocatalyst was up to $0.55 \mu \mathrm{mol} / \mathrm{h} / \mathrm{g}$. This experiment proved that perovskite-type oxide semiconductor photocatalysts with conduction bands dominated by $4 \mathrm{f}$ electronic configuration could also react as well as the semiconductor photocatalysts with $\mathrm{d}^{0}$ electronic configuration in gas phase $\mathrm{CO}_{2}$ photoreduction.

\section{Summary and outlook}

The photocatalytic reduction of $\mathrm{CO}_{2}$ into renewable hydrocarbon fuels using solar energy is a promising approach for simultaneously achieving carbon cycling and solving the shortage of sustainable energy. An ideal semiconductor photocatalyst for
$\mathrm{CO}_{2}$ photoreduction should have a suitable $E_{\mathrm{g}}$ and proper positioning of the $\mathrm{CB}$ and $\mathrm{VB}$, which should satisfy thermodynamic conditions of $\mathrm{CO}_{2}$ reduction. In addition, the photogenerated electron-hole pairs should separate effectively and transfer to the surface active sites of the semiconductor photocatalysts so that they can participate in the oxidation-reduction reactions with $\mathrm{CO}_{2}$ and $\mathrm{H}_{2} \mathrm{O}$.

The photocatalytic reduction of $\mathrm{CO}_{2}$ is a complex multielectronic reaction process. The main products in a gas phase $\mathrm{CO}_{2}$ reduction are generally $\mathrm{CH}_{4}$ as well as a small amount of $\mathrm{CO}$, and the yield of $\mathrm{CH}_{4}$ is usually on the $\mu \mathrm{mol}$ scale. This yield is relatively low compared with the conversion of water splitting. ${ }^{[14-16,45-54]}$ The conversion efficiency and
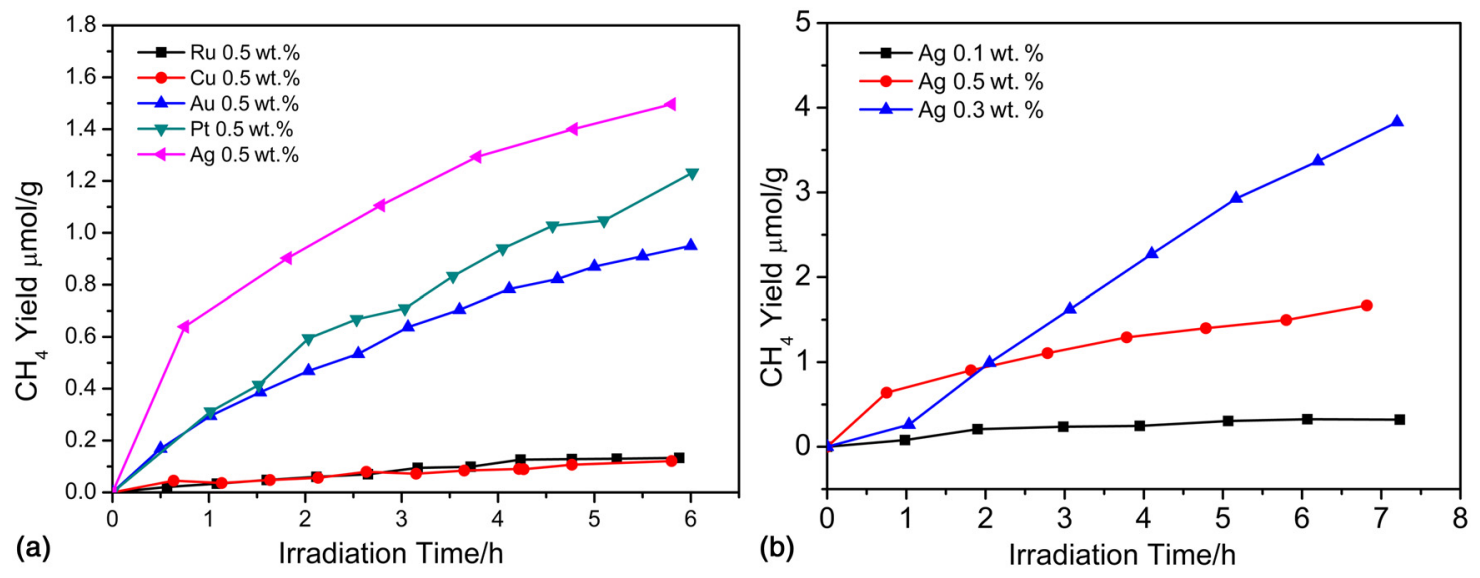

Figure 6. (a) $\mathrm{CH}_{4}$ yields of $\mathrm{BaZrO}_{3}$ deposited with different cocatalysts ( $\mathrm{Ru}, \mathrm{Cu}, \mathrm{Au}, \mathrm{Pt}, \mathrm{Ag}$ ) of the same apparent amount. (b) $\mathrm{CH}_{4}$ yields of $\mathrm{BaZrO}_{3}$ with different amounts of Ag deposition. (Copyright 2015, Catalysis Science \& Techonology. ${ }^{[14]}$ ). 
products selectivity of gaseous $\mathrm{CO}_{2}$ photoreduction not only depends on the characteristics of the photocatalyts but also depends on some experimental conditions, such as the light source, response time, reaction temperature, the ratio of $\mathrm{H}_{2} \mathrm{O}$ and $\mathrm{CO}_{2}$, etc. It is necessary to verify whether the formation of hydrocarbon products is actually from the photocatalytic reduction of $\mathrm{CO}_{2}$ or is from some side reactions with organic adsorbates (e.g., acetic acid) or carbon residues. These adsorbates or residues may be formed during the photo-Kolbe reaction, mineralization reaction or reverse disproportionation reaction in photocatalytic reaction. A series of contrast experiments with different conditions (including $\mathrm{H}_{2} \mathrm{O}, \mathrm{CO}_{2}$, irradiation and catalyst) or a more intuitive and precise method-isotopic labeling $\left({ }^{13} \mathrm{C}\right.$ and $\left.{ }^{18} \mathrm{O}\right)$ - is necessary to detect and/or exclude the effects of carbon residues and organic adsorbates. These contaminants can also be removed by thermal treatment in air or inert gas or by prolonged washing with water upon the formation of products.

Based on the research and the current development of related theories and practical applications, the photocatalytic reduction of $\mathrm{CO}_{2}$ still has a long way to go. The future studies on $\mathrm{CO}_{2}$ photoreduction should be initiated in the following areas.

\section{Developing a new suitable photocatalyst}

As we mentioned above, a wide variety of perovskite oxide semiconductors system have been applied to the photocatalytic reduction of $\mathrm{CO}_{2}$ in a gas reaction system under $\mathrm{UV}$ or visible light irradiation. Most of them consist of metal cations with $\mathrm{d}^{0}$ configurations including tantalates, niobates, titanates, zirconates, with the exception being cerates such as $\mathrm{BaCeO}_{3}$ with $4 \mathrm{f}$ orbitals electron configurations. It is believed that perovskite oxide semiconductor photocatalysts still have great prospects due to their unique physical and chemical properties in the future study of the photocatalytic reduction of $\mathrm{CO}_{2}$. For example, alkaline earth stannates of $\mathrm{MSnO}_{3}(\mathrm{M}=\mathrm{Ca}, \mathrm{Sr}$ and $\mathrm{Ba})$, which contain $\mathrm{Sn}^{4+}$ ions with a d ${ }^{10}$ electronic configuration, have been used as the photocatalyst applied to photocatalytic reactions for $\mathrm{H}_{2}$ and $\mathrm{O}_{2}$ evolution in water splitting. ${ }^{[55]}$ The bottom of the CBs are located at $-1.46,-1.37$ and $-0.69 \mathrm{~V}$ (versus NHE, $\mathrm{pH}=7$ ) for $\mathrm{CaSnO}_{3}, \mathrm{SrSnO}_{3}$ and $\mathrm{BaSnO}_{3}$, respectively, while the top of the VBs are 2.98, 2.69 and $2.41 \mathrm{~V}$ (versus NHE, $\mathrm{pH}=7$ ), respectively. Thus, the photogenerated electrons in the $\mathrm{CB}$ are more negative than the reduction potentials of $\mathrm{CO}_{2}$ into $\mathrm{HCOOH}, \mathrm{CO}, \mathrm{HCHO}, \mathrm{CH}_{3} \mathrm{OH}$ and $\mathrm{CH}_{4}$, and the corresponding photogenerated holes in the $\mathrm{VB}$ can easily oxidize $\mathrm{H}_{2} \mathrm{O}$ in the $\mathrm{ABO}_{3}$ structure of these stannates. In other words, $\mathrm{MSnO}_{3}(\mathrm{M}=\mathrm{Ca}, \mathrm{Sr}$ and $\mathrm{Ba})$ is theoretically feasible as a photocatalyst for the reduction of $\mathrm{CO}_{2}$. In addition, our group has already tested the photocatalytic reduction of $\mathrm{CO}_{2}$ over $\mathrm{BaSnO}_{3}$, and we hope that $\mathrm{MSnO}_{3}(\mathrm{M}=\mathrm{Ca}, \mathrm{Sr}$ and $\mathrm{Ba})$ will be a promising photocatalyst for the gas phase photoreduction of $\mathrm{CO}_{2}$ in future.

In addition, double perovskite oxides with the general chemical formula of $\mathrm{A}_{2} \mathrm{BB}^{\prime} \mathrm{O}_{6}$ have attracted much interest due to their variable crystal structures, flexible chemical compositions and other unique physicochemical properties such as being semi-metallic. These catalysts have been successfully applied to water splitting, such as $\mathrm{Ba}_{2} \mathrm{InTaO}_{6}$ with a $E_{\mathrm{g}}$ of ca. $4.17 \mathrm{eV} .{ }^{[56]} \mathrm{A}$ variety of elements are available for substitution into the A or B site; B site elements are usually transition metals with d-orbital configurations, and $\mathrm{A}$ site elements are usually alkaline earth ions such as $\mathrm{Ca}, \mathrm{Sr}$ and $\mathrm{Ba}^{[57]}$ Based on these results, development of new double perovskite oxide semiconductors system seem to be one feasible direction for research on $\mathrm{CO}_{2}$ reduction in future.

\section{Cocatalysts}

It is generally believed that cocatalysts play a crucial role in semiconductor-based photocatalysis. ${ }^{[3,4,58]}$ Firstly, loaded cocatalysts could serve as electron traps to promote the separation of photogenerated electron-hole pairs resulting from the formation of a Schottky barrier between the semiconductor and the cocatalyst. Hence, they could improve the photocatalytic activity and selectivity for $\mathrm{CO}_{2}$ reduction. Secondly, cocatalysts could effectively lower the activation barrier of $\mathrm{CO}_{2}$ due to their better conductivity and lower over potential. ${ }^{[59,60]}$ To date, a series of cocatalysts including $\mathrm{Pd}, \mathrm{Pt}, \mathrm{Au}, \mathrm{Ag}, \mathrm{Ru}, \mathrm{Cu}$, $\mathrm{Ni}, \mathrm{Co}$, etc. have been used for photocatalytic reactions, and each presented different effects on the conversion efficiency. ${ }^{[26,45,61]}$ In addition, it is worth noticing that the bimetallic cocatalyst systems (such as $\mathrm{Cu}$ and $\mathrm{Pt}$ ) have also exhibited good activities for $\mathrm{CO}_{2}$ reduction, ${ }^{[62]}$ and the enhancement mechanism is still unclear. Thus, it is essential to better understand the photocatalytic mechanism of cocatalysts and to develop cheap, abundant and highly efficient cocatalyst systems (e.g., non-noble metal cocatalysts and new-type bifunctional cocatalysts with a proper structure) for the photocatalytic reduction of $\mathrm{CO}_{2}$.

\section{Gas adsorption ability on the surface of photocatalysts}

It is well known that the reduction of $\mathrm{CO}_{2}$ and the oxidation of $\mathrm{H}_{2} \mathrm{O}$ are the two main half-reaction steps for the photocatalytic reduction of $\mathrm{CO}_{2}$. On one hand, effective adsorption of $\mathrm{CO}_{2}$ is an important process that can be promoted by increasing surface area, ${ }^{[29]}$ by introducing basic sites such as $\mathrm{MgO}$, or by introducing surface oxygen vacancies ${ }^{[16,63]}$. Optimization of adsorption is important for improving the conversion efficiency for the photocatalytic reduction of $\mathrm{CO}_{2}$. The adsorption of $\mathrm{CO}_{2}$ molecules on stoichiometric and oxygen-deficient $\mathrm{SrTiO}_{3}$ has been theoretically and experimentally studied by Xie et al. They demonstrated that chemical adsorption of $\mathrm{CO}_{2}$ molecules could be improved by increasing the oxygen deficiency in $\mathrm{SrTiO}_{3}$, thus enhancing the photocatalytic performance for $\mathrm{CO}_{2}$ reduction. ${ }^{[16]}$ On the other hand, water oxidation favors the efficient separation of the photogenerated electron-hole pairs, thus improving the photocatalytic activity for $\mathrm{CO}_{2}$ reduction. ${ }^{[3,19]}$ In addition, deactivation of the photocatalysts may occur after long reaction times, which may be attributed to the active sites gradually becoming covered by the adsorption 
of the reduction intermediate products or the final products accumulation on the photocatalyst surface over time. ${ }^{[32,64]}$ In conclusion, it is important to refine the research on the adsorption of gaseous reactants $\left(\mathrm{CO}_{2}, \mathrm{H}_{2} \mathrm{O}\right)$ and the products on the surface of photocatalysts.

In short, the future development for the photocatalytic reduction of $\mathrm{CO}_{2}$ remains challenging, and the comprehensive efforts (such as materials synthesis, doping, nanostructuring and heterojunction $)^{[4,25]}$ are needed to achieve a breakthrough in the conversion efficiency of $\mathrm{CO}_{2}$ reduction into hydrocarbon fuels that may eventually lead to industrialization.

\section{Acknowledgments}

This work is supported by National Basic Research Program of China (973 Program, 2013CB632404), a Project Funded by the Priority Academic Program Development of Jiangsu Higher Education Institutions, New Century Excellent Talents in University (NCET-12-0268), and the National Natural Science Foundation of China (Nos. 21473090 and 51272102).

\section{References}

1. Z.S. Li, J.Y. Feng, S.C. Yan, and Z.G. Zou: Solar fuel production: strategies and new opportunities with nanostructures. Nano Today 10, 468 (2015).

2. J.L. White, M.F. Baruch, J.E. Pander III, Y. Hu, I.C. Fortmeyer, J.E. Park, T. Zhang, K. Liao, J. Gu, Y. Yan, T.W. Shaw, E. Abelev, and A.B. Bocarsly: Light-driven heterogeneous reduction of carbon dioxide: photocatalysts and photoelectrodes. Chem. Rev. 115, 12888 (2015).

3. X. Li, J.Q. Wen, J.X. Low, Y.P. Fang, and J.G. Yu: Design and fabrication of semiconductor photocatalyst for photocatalytic reduction of $\mathrm{CO}_{2}$ to solar fuel. Sci. China Mater. 57, 70 (2014).

4. W.G. Tu, Y. Zhou, and Z.G. Zou: Photocatalytic conversion of $\mathrm{CO}_{2}$ into renewable hydrocarbon fuels: state-of-the-art accomplishment, challenges, and prospects. Adv. Mater. 26, 4607 (2014).

5. K.F. Li, X.Q. An, K.H. Park, M. Khraisheh, and J.W. Tang: A critical review of $\mathrm{CO}_{2}$ photoconversion: catalysts and reactors. Catal. Today 224, 3 (2014).

6. T. Inoue, A. Fujishima, S. Konishi, and K. Honda: Photoelectrocatalytic reduction of carbon dioxide in aqueous suspensions of semiconductor powders. Nature 277, 637 (1979).

7. S.N. Habisreutinger, L. Schmidt-Mende, and J.K. Stolarczyk: Photocatalytic reduction of $\mathrm{CO}_{2}$ on $\mathrm{TiO}_{2}$ and other semiconductors. Angew. Chem. Int. Ed. 52, 7372 (2013).

8. L.J. Liu, H.L. Zhao, J.M. Andino, and Y. Li: Photocatalytic $\mathrm{CO}_{2}$ reduction with $\mathrm{H}_{2} \mathrm{O}$ on $\mathrm{TiO}_{2}$ nanocrystals: comparison of anatase, rutile, and brookite polymorphs and exploration of surface chemistry. ACS Catal. 2, 1817 (2012).

9. S. Wang and $\mathrm{X}$. Wang: Photocatalytic $\mathrm{CO}_{2}$ reduction by CdS promoted with a zeolitic imidazolate framework. Appl. Catal. B-Environ. 162, 494 (2015).

10. E.E. Barton, D.M. Rampulla, and A.B. Bocarsly: Selective solar-driven reduction of $\mathrm{CO}_{2}$ to methanol using a catalyzed $\mathrm{p}-\mathrm{GaP}$ based photoelectrochemical cell. J. Am. Chem. Soc. 130, 6342 (2008).

11.S.C. Yan, J.J. Wang, and Z.G. Zou: An anion-controlled crystal growth route to $\mathrm{Zn}_{2} \mathrm{GeO}_{4}$ nanorods for efficient photocatalytic conversion of $\mathrm{CO}_{2}$ into $\mathrm{CH}_{4}$. Dalton Trans. 42, 12975 (2013).

12. H. Kato and $A$. Kudo: Water splitting into $\mathrm{H}_{2}$ and $\mathrm{O}_{2}$ on alkali tantalite photocatalysts $\mathrm{ATaO}_{3}(\mathrm{~A}=\mathrm{Li}, \mathrm{Na}$, and K). J. Phys. Chem. B. 105, 4285 (2001).

13. A. Kudo, $\mathrm{H}$. Kato, and S. Nakagawa: Water splitting into $\mathrm{H}_{2}$ and $\mathrm{O}_{2}$ on new $\mathrm{Sr}_{2} \mathrm{M}_{2} \mathrm{O}_{7}(\mathrm{M}=\mathrm{Nb}$ and $\mathrm{Ta}$ ) photocatalysts with layered perovskite structure: factors affecting the photocatalytic activity. J. Phys. Chem. B. 104, 571 (2000).
14.X.L. Chen, J. Wang, C.X. Huang, S.Y. Zhang, H.T. Zhang, Z.S. Li, and Z.G. Zou: Barium zirconate: a new photocatalyst for converting $\mathrm{CO}_{2}$ into hydrocarbons under UV irradiation. Catal. Sci. Technol. 5, 1758 (2015).

15.J. Wang, C.X. Huang, X.L. Chen, H.T. Zhang, Z.S. Li, and Z.G. Zou: Photocatalytic $\mathrm{CO}_{2}$ reduction of $\mathrm{BaCeO}_{3}$ with $4 \mathrm{f}$ configuration electrons. Appl. Surf. Sci. 358, 463 (2015).

16. K. Xie, N. Umezawa, N. Zhang, P. Reunchan, Y.J. Zhang, and J.H. Ye: Self-doped $\mathrm{SrTiO}_{3-\delta}$ photocatalyst with enhanced activity for artificial photosynthesis under visible light. Energy Environ. Sci. 4, 4211 (2011).

17. K. Mori, H. Yamashita, and M. Anpo: Photocatalytic reduction of $\mathrm{CO}_{2}$ with $\mathrm{H}_{2} \mathrm{O}$ on various titanium oxide photocatalysts. $R S C$ Adv. 2, 3165 (2012).

18. M. Anpo and K. Chiba: Photocatalytic reduction of $\mathrm{CO} 2$ on anchored titanium oxide catalysts. J. Mole. Catal. 74, 207 (1992).

19. Y. Izumi: Recent advances in the photocatalytic conversion of carbon dioxide to fuels with water and/or hydrogen using solar energy and beyond. Coordin. Chem. Rev. 257, 171 (2013).

20. G.R. Dey: Chemical reduction of $\mathrm{CO}_{2}$ to different products during photo catalytic reaction on $\mathrm{TiO}_{2}$ under diverse conditions: an overview. J. Nat. Gas Chem. 16, 217 (2007).

21. V.P. Indrakanti, J.D. Kubicki, and H.H. Schobert: Photoinduced activation of $\mathrm{CO}_{2}$ on Ti-based heterogeneous catalysts: current state, chemical physics-based insights and outlook. Energy Environ. Sci. 2, 745 (2009).

22. S.C. Roy, O.K. Varghese, M. Paulose, and C.A. Grimes: Toward solar fuels: photocatalytic conversion of carbon dioxide to hydrocarbons. ACS Nano 4, 1259 (2010).

23. J. Schneider, H. Jia, J.T. Muckerman, and E. Fujita: Thermodynamics and kinetics of $\mathrm{CO}_{2}, \mathrm{CO}$, and $\mathrm{H}^{+}$binding to the metal centre of $\mathrm{CO}_{2}$ reduction catalysts. Chem. Soc. Rev. 41, 2036 (2012).

24. S. Sato, T. Morikawa, S. Saeki, T. Kajino, and T. Motohiro: Visible-light-induced selective $\mathrm{CO}_{2}$ reduction utilizing a ruthenium complex electrocatalyst linked to a p-type nitrogen-doped $\mathrm{Ta}_{2} \mathrm{O}_{5}$ Semiconductor. Angew. Chem. Int. Ed. 49, 5101 (2010).

25. N. Zhang, S.X. Ouyang, T. Kako, and J.H. Ye: Mesoporous zinc germanium oxynitride for $\mathrm{CO}_{2}$ photoreduction under visible light. Chem. Commun. 48, 1269 (2012).

26. O. Ishitani, C. Inoue, Y. Suzuki, and T. Ibusuki: Photocatalytic reduction of carbon dioxide to methane and acetic acid by an aqueous suspension of metal-deposited $\mathrm{TiO}_{2}$. J. Photochem. Photobio. A: Chem. 72, 269 (1993).

27. B.J. Liu, T. Torimoto, H. Matsumoto, and H. Yoneyama: Effect of solvents on photocatalytic reduction of carbon dioxide using $\mathrm{TiO}_{2}$ nanocrystal photocatalyst embedded in $\mathrm{SiO}_{2}$ matrices. J. Photochem. Photobio. A: Chem. 108, 187 (1997)

28. G.C. Xi, S.X. Ouyang, and J.H. Ye: General synthesis of hybrid $\mathrm{TiO}_{2}$ mesoporous "french fries" toward improved photocatalytic conversion of $\mathrm{CO}_{2}$ into hydrocarbon fuel: a case of $\mathrm{TiO}_{2} / \mathrm{ZnO}$. Chem. Eur. J. 17, 9057 (2011).

29. D.K. Wang, R.K. Huang, W.J. Liu, D.R. Sun, and Z.H. Li: Fe-based MOFs for photocatalytic $\mathrm{CO}_{2}$ reduction: role of coordination unsaturated sites and dual excitation pathways. ACS Catal. 4, 4254 (2014).

30. Q.G. Zhai, S.J. Xie, W.Q. Fan, Q.H. Zhang, Y. Wang, W.P. Deng, and Y. Wang: Photocatalytic conversion of carbon dioxide with water into methane: platinum and copper(I) oxide co-catalysts with a core-shell structure. Angew. Chem. 125, 5888 (2013).

31. A.H. Yahaya, M.A. Gondal, and A. Hameed: Selective laser enhanced photocatalytic conversion of $\mathrm{CO}_{2}$ into methanol. Chem. Phys. Lett. 400, 206 (2004).

32.Z.H. Zhao, J.M. Fan, S.H. Liu, and Z.Z. Wang: Optimal design and preparation of titania-supported $\mathrm{CoPc}$ using sol-gel for the photo-reduction of $\mathrm{CO}_{2}$. Chem. Eng. J. 151, 134 (2009).

33. Q.H. Zhang, W.D. Han, Y.J. Hong, and J.G. Yu: Photocatalytic reduction of $\mathrm{CO}_{2}$ with $\mathrm{H}_{2} \mathrm{O}$ on Pt-loaded $\mathrm{TiO}_{2}$ catalyst. Catal. Today 148, 335 (2009).

34. K. Ikeue, S. Nozaki, M. Ogawa, and M. Anpo: Characterization of selfstanding Ti-containing porous silica thin films and their reactivity for the photocatalytic reduction of $\mathrm{CO}_{2}$ with $\mathrm{H}_{2} \mathrm{O}$. Catal. Today 74, 241 (2002).

35. C.C. Yang, Y.H. Yu, B. van der Linden, and J.C.S. Wu: Artificial photosynthesis over crystalline $\mathrm{TiO}_{2}$-based catalysts: fact or fiction? J. Am. Chem. Soc. 132, 8398 (2010).

36. T. Yui, A. Kan, C. Saitoh, K. Koike, T. Ibusuki, and 0. Ishitani: Photochemical reduction of $\mathrm{CO}_{2}$ using $\mathrm{TiO}_{2}$ : effects of organic adsorbates 
on $\mathrm{TiO}_{2}$ and deposition of $\mathrm{Pd}$ onto $\mathrm{TiO}_{2}$. ACS Appl. Mater. Inter. 3, 2594 (2011).

37.P. Li, Y. Zhou, H.J. Li, Q.F. Xu, X.G. Meng, X.Y. Wang, M. Xiao, and Z.G. Zou: All-solid-state Z-scheme system arrays of $\mathrm{Fe}_{2} \mathrm{~V}_{4} \mathrm{O}_{13} / \mathrm{RGO} / \mathrm{CdS}$ for visible light-driving photocatalytic $\mathrm{CO}_{2}$ reduction into renewable hydrocarbon fuel. Chem. Commun. 51, 800 (2015).

38. K. Kočí, L. Obalová, L. Matějová, D. Placháa, Z. Lacnýa, J. Jirkovskýc, and 0 . Šolcová: Effect of $\mathrm{TiO}_{2}$ particle size on the photocatalytic reduction of $\mathrm{CO}_{2}$. Appl. Catal. B: Environ. 89, 494 (2009).

39. W.Y. Lin and H. Frei: Bimetallic redox sites for photochemical $\mathrm{CO}_{2}$ splitting in mesoporous silicate sieve. Comptes Rendus Chimie. 9, 207 (2006).

40.G. Mahmodi, S. Sharifnia, F. Rahimpour, and S.N. Hosseini.: Photocatalytic conversion of $\mathrm{CO}_{2}$ and $\mathrm{CH}_{4}$ using $\mathrm{ZnO}$ coated mesh: effect of operational parameters and optimization. Solar Energy Mater. Solar Cells 111, 31 (2013).

41. Y.Y. Liu, B.B. Huang, Y. Dai, X.Y. Zhang, X.Y. Qin, M.H. Jiang, and M. $H$. Whangbo: Selective ethanol formation from photocatalytic reduction of carbon dioxide in water with $\mathrm{BiVO}_{4}$ photocatalyst. Catal. Commun. 11, 210 (2009).

42. H. Park, J.H. Choi, K.M. Choi, D.K. Lee, and J.K. Kang: Highly porous gallium oxide with a high $\mathrm{CO}_{2}$ affinity for the photocatalytic conversion of carbon dioxide into methane. J. Mater. Chem. 22, 5304 (2012).

43. H. Fujiwara, H. Hosokawa, K. Murakoshi, Y. Wada, and S. Yanagida: Surface characteristics of ZnS nanocrystallites relating to their photocatalysis for $\mathrm{CO}_{2}$ reduction1. Langmuir 14, 5154 (1998).

44. J. Mao, T.Y. Peng, X.H. Zhang, K. Li, L.Q. Ye, and L. Zan: Effect of graphitic carbon nitride microstructures on the activity and selectivity of photocatalytic $\mathrm{CO}_{2}$ reduction under visible light. Catal. Sci. Technol. 3, 1253 (2013).

45.H. Zhou, J.J. Guo, P. Li, T.X. Fan, D. Zhang, and J.H. Ye: Leaf-architectured 3D hierarchical artificial photosynthetic system of perovskite titanates towards $\mathrm{CO}_{2}$ photoreduction into hydrocarbon fuels. Sci. Rep. 3, 1 (2013).

46. J.H. Kou, J. Gao, Z.S. Li, H. Yu, Y. Zhou, and Z.G. Zou: Construction of visible-light-responsive $\mathrm{SrTiO}_{3}$ with enhanced $\mathrm{CO}_{2}$ adsorption ability: highly efficient photocatalysts for artifical photosynthesis. Catal. Lett. 145, 640 (2015).

47. B.S. Kwak and M. Kang: Photocatalytic reduction of $\mathrm{CO}_{2}$ with $\mathrm{H}_{2} \mathrm{O}$ using perovskite $\mathrm{Ca}_{x} \mathrm{Ti}_{\mathrm{y}} \mathrm{O}_{3}$. Appl. Surf. Sci. 337, 138 (2015).

48. X.K. Li, H.Q. Pan, W. Li, and Z.J. Zhuang: Photocatalytic reduction of $\mathrm{CO}_{2}$ to methane over $\mathrm{HNb}_{3} \mathrm{O}_{8}$ nanobelts. Appl. Catal. A: Gen. 413-414, 103 (2012).

49.X.K. Li, W. Li, Z.J. Zhuang, Y.S. Zhong, Q. Li, and L.Y. Wang: Photocatalytic reduction of carbon dioxide to methane over $\mathrm{SiO}_{2}$-pillared $\mathrm{HN}_{3} \mathrm{O}_{8}$. J. Phys. Chem. C. 116, 16047 (2012).

50.P. Li, S.X. Ouyang, Y.J. Zhang, T. Kako, and J.H. Ye: Surface-coordination-induced selective synthesis of cubic and orthorhombic $\mathrm{NaNbO}_{3}$ and their photocatalytic properties. J. Mater. Chem. A. 1, 1185 (2013).

51.P. Li, S.X. Ouyang, G.C. Xi, T. Kako, and J.H. Ye: The effects of crystal structure and electronic structure on photocatalytic $\mathrm{H}_{2}$ evolution and $\mathrm{CO}_{2}$ reduction over two phases of perovskite-structured $\mathrm{NaNbO}_{3}$. J. Phys. Chem. C. 116, 7621 (2012).

52. H.F. Shi and Z.G. Zou: Photophysical and photocatalytic properties of $\mathrm{ANbO}_{3}(\mathrm{~A}=\mathrm{Na}, \mathrm{K})$ photocatalysts. J. Phys. Chem. Solids 73, 788 (2012).

53.H.F. Shi, T.Z. Wang, J. Chen, C. Zhu, J.H. Ye, and Z.G. Zou: Photoreduction of carbon dioxide over $\mathrm{NaNbO}_{3}$ nanostructured photocatalysts. Catal. Lett. 141, 525 (2011).

54. K. Teramura, S. Okuoka, H. Tsuneoka, T. Shishido, and T. Tanaka: Photocatalytic reduction of $\mathrm{CO}_{2}$ using $\mathrm{H}_{2}$ as reductant over $\mathrm{ATaO}_{3}$ photocatalysts $(\mathrm{A}=\mathrm{Li}, \mathrm{Na}, \mathrm{K})$. Appl. Catal. B: Environ. 96, 565 (2010).

55. W.F. Zhang, J.W. Tang, and J.H. Ye: Structural, photocatalytic, and photophysical properties of perovskite $\mathrm{MSnO}_{3}(\mathrm{M}=\mathrm{Ca}, \mathrm{Sr}$, and $\mathrm{Ba}$ ) photocatalysts. J. Mater. Res. 22, 1859 (2007).

56. K. Song, J. Yang, P.F. Jiang, W.L. Gao, R.H. Cong, and T. Yang: $\mathrm{Ba}_{2} \mathrm{InTaO}_{6}-\mathrm{A}$ partially $\mathrm{B}$-site-ordered double perovskite for overall water splitting. Eur. J. Inorg. Chem. 2015, 5786 (2015).
57. L. Li, Q. Gao, G. Lei, H.H. Xie, J.B. Deng, and X.R. Hu: First-principles investigations on electronic and thermodynamic properties of double perovskite $\mathrm{Sr}_{2} \mathrm{XMoO}_{6}$ (X=Ge and Si). J. Phys. Chem. Solids 94, 30 (2016).

58. J.H. Yang, D.G. Wang, H.X. Han, and C. Li: Roles of cocatalysts in photocatalysis and photoelectrocatalysis. Acc. Chem. Res. 46, 1900 (2013).

59. F.E. Osterloh and B.A. Parkinson: Recent developments in solar watersplitting photocatalysis. MRS Bull. 36, 17 (2011).

60. K. Maeda and K. Domen: Photocatalytic water splitting: recent progress and future challenges. J. Phys. Chem. Lett. 1, 2655 (2010).

61. S. Fukuzumi, D. Hong, and Y. Yamada: Bioinspired photocatalytic water reduction and oxidation with earth-abundant metal catalysts. J. Phys. Chem. Lett. 4, 3458 (2013).

62. O.K. Varghese, M. Paulose, T.J. LaTempa, and C.A. Grimes: High-rate solar photocatalytic conversion of $\mathrm{CO}_{2}$ and water vapor to hydrocarbon fuels. Nano Lett. 9, 731 (2009).

63. S.J. Xie, Y. Wang, Q.H. Zhang, W.P. Deng, and Y. Wang: MgO- and Pt-promoted $\mathrm{TiO}_{2}$ as an efficient photocatalyst for the preferential reduction of carbon dioxide in the presence of water. ACS Catal. 4, 3644 (2014).

64.Z. Xiong, Y.C. Zhao, J.Y. Zhang, and C.G. Zheng: Efficient photocatalytic reduction of $\mathrm{CO}_{2}$ into liquid products over cerium doped titania nanoparticles synthesized by a sol-gel auto-ignited method. Fuel Process. Technol. 135, 6 (2015). 